\title{
LAST PLANNER SYSTEM (LPS) IMPLEMENTATION ON JAKARTA-CIKAMPEK II ELEVATED TOLL ROAD PROJECT
}

\author{
Ni’mah Tozahro' ${ }^{1}$, Afrizal Nursin ${ }^{2}$ \\ ${ }^{1,2}$ Politeknik Negeri Jakarta, Jurusan Teknik Sipil, Jl. Prof. Dr. G.A Siwabessy, Kampus Baru UI, Beji, \\ Kukusan, Beji, Kota Depok, Tlp.+6221 7270036, Fax (021) 7270034, 16425. \\ e-mail : nimah.tozahro@gmail.com ${ }^{I}$
}

\begin{abstract}
In construction industry, its implementation of the construction has its own constraints. A good management or project management system is needed to minimize the risk of these constraints. The latest project management concept that has proven more effective and efficient is Last Planner System method. This study aims to investigate how the implementation of Last Planner System works on JakartaCikampek II Elevated Toll Road Project. With the evaluation of weekly job evaluations using PPC (Percent Plan Completed) and Pareto Variance Constraint analysis, the constraint issues of this project will be identified. Then they are followed up to find the right solution in handling the constraints. The research method is done by conducting literature study, problem formulation, followed by implementing LPS method, which is through work flow control such as phase and pull plan, lookahead plan, constrain analysis, daily huddles, PPC (Percent Plan Completed) calculation, Pareto Chart analysis with data variation of issues that have been obtained. The results show that the average PPC weekly project is $83.04 \%$ and the most influential reason that must be concerned its priority is submittals.
\end{abstract}

Keywords : Constrains; Last Planner System; Percent Plan Completed; Pareto Chart

\section{INTRODUCTION}

\section{Research Background}

Every implementation of the construction industry has its own constraints. It causes unmatching to the plan that has already been made on working contract document. The unmatched finishing time of construction work with the working contract is called detainment.

Jakarta-Cikampek II Elevated Toll Road Project is one of the projects that is detained/overdue (PT Jasa Marga Jalan Layang Cikampek, 2019). On the agreed plan contract, this project could be operated since March 2019, but because of the constraints during the development progress, this project was finished beyond the agreed target.

The detainment on construction project very depends on the project management or system that is implemented on the project. The latest project management concept and has proven more effective and efficient is Last Planner System method.

Therefore, this research attempts to implement the Last Planner System (LPS) concept to study the management process on the Jakarta-Cikampek II Elevated Toll Road Project.

The objective of this research is to investigate the implementation of Last Planner System (LPS) concept on JakartaCikampek II Elevated Toll Road Project (Nursin, 2019), to evaluate the working performance with Percent Plan Completed (PPC), and with Pareto chart analysis to investigate the proper follow-up for issues on Jakarta-Cikampek II Elevated Toll Road Project. 


\section{RESEARCH METHOD}

\section{Research Location}

Jakarta-Cikampek II Elevated Toll Road Project length is $36.84 \mathrm{~km}$, located on Cikunir - West Karawang, West Java, Indonesia (PT Jasa Marga Jalan Layang Cikampek, 2019). The focus of this research was conducted on the project in Zone 3, Section 2 (SS, West Bekasi - East Bekasi).

\section{Research Design}

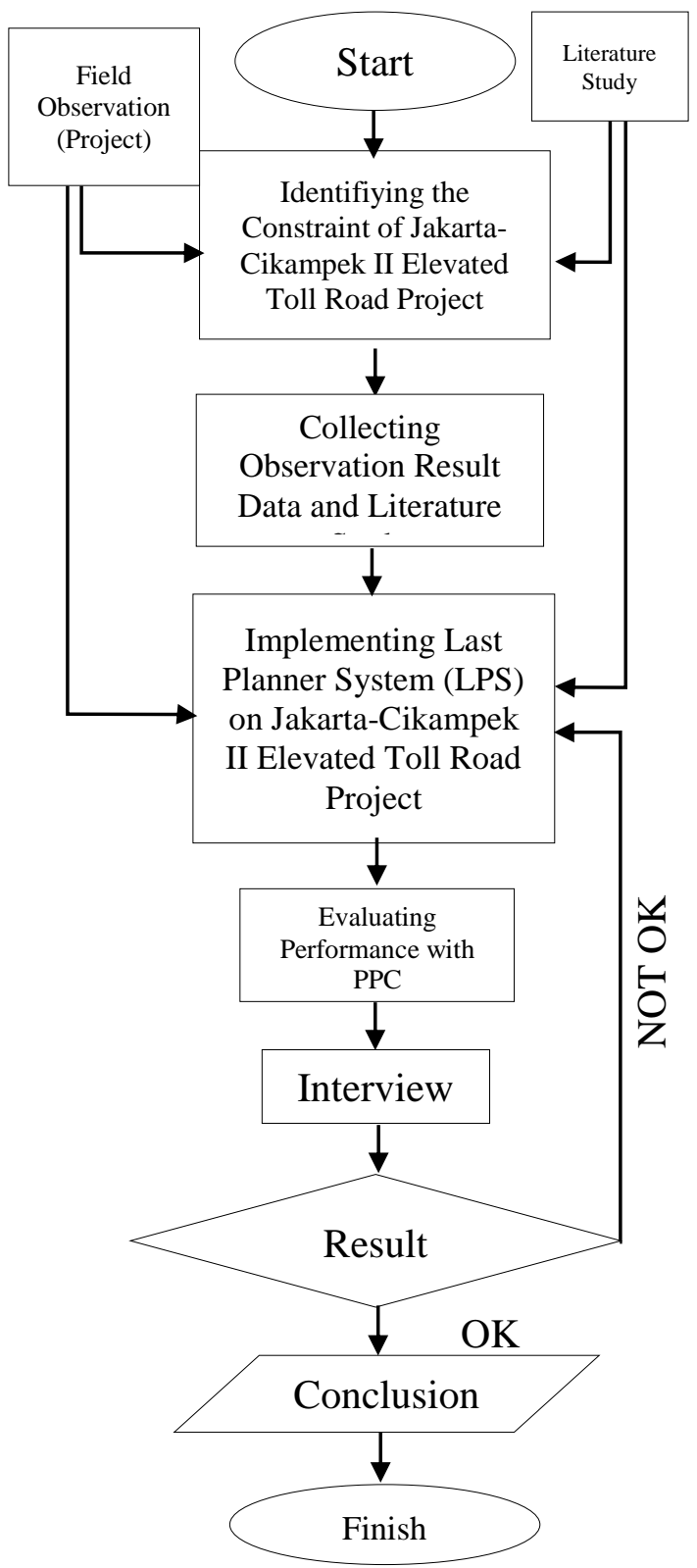

\section{RESULT AND DISCUSSION}

Because the research period was limited, it was only six weeks taken for PPC observation (Ballard, 2000). It started since week 108 to week 113. The week 113 was the last week before the project was restored for Eid Mubarak 1440 Hijriyah. Period of 14 April 2019 until 25 May 2019.

The scope of works observed were:

1) Erection Girder

2) Link Slab

3) Parapet

4) Rigid

5) Access Asphalting

6) Cap-piling

\section{LPS Working System Control}

\section{1) Master Schedule}

The Master Schedule on JakartaCikampek II Elevated Toll Road Project is taken from S Curve which is interpreted into a schedule. S Curve is used as the measure for work objectives which have to be completed by the project team each week.

\section{2) Phase and Pull Planning}

Phase planning and Pull Planning interprets main works on the S Curve into work details to meet the main work requirements. Those works are managed accordingly and timely (Arifin, 2017).

\section{3) Lookahead Planning}

The works resulted from Phase and Pull Planning are broken down into the stage of process/ operation, the constrain issues are identified, the responsibilities are delegated to each person (executor), and the assignments are ready to be done (Hamzeh, Ballard, \& Tommelein, 2008) 
The constrains identification result on Jakarta-Cikampek II Elevated Toll Road Project are presented on Table 1.

Table 1. Lookahead Planning Issues Identification

\begin{tabular}{|c|c|c|}
\hline Works & $\begin{array}{l}\text { Estimat } \\
\text { ed } \\
\text { Cons- } \\
\text { trains }\end{array}$ & Handling \\
\hline $\begin{array}{l}\text { Erection } \\
\text { Girder }\end{array}$ & $\begin{array}{l}\text { Sub- } \\
\text { Contract } \\
\text { or } \\
\text { Overdue }\end{array}$ & $\begin{array}{l}\text { Contacting Sub- } \\
\text { Contractor Once } \\
\text { A Week regarding } \\
\text { schedule }\end{array}$ \\
\hline $\begin{array}{l}\text { Link } \\
\text { Slab } \\
\text { Reinforci } \\
\text { ng }\end{array}$ & $\begin{array}{l}\text { Workers } \\
\text { Mobiliz } \\
\text { ation } \\
\text { Without } \\
\text { Scaffold } \\
\text { ing } \\
\text { Ladder }\end{array}$ & $\begin{array}{l}\text { Providing Man- } \\
\text { Lift }\end{array}$ \\
\hline $\begin{array}{l}\text { Link } \\
\text { Slab } \\
\text { Casting }\end{array}$ & $\begin{array}{l}\text { Highwa } \\
\text { y Patrol } \\
\text { Permissi } \\
\text { on }\end{array}$ & $\begin{array}{l}\text { Filing a permit } \\
\text { and project } \\
\text { schedule to the } \\
\text { Traffic Team }\end{array}$ \\
\hline $\begin{array}{l}\text { Deck } \\
\text { Slab } \\
\text { Reinforci } \\
\text { ng }\end{array}$ & $\begin{array}{l}\text { Finished } \\
\text { Overdue }\end{array}$ & Adding Workers \\
\hline $\begin{array}{l}\text { Deck } \\
\text { Slab } \\
\text { Casting }\end{array}$ & $\begin{array}{l}\text { Highwa } \\
\text { y Patrol } \\
\text { Permissi } \\
\text { on }\end{array}$ & $\begin{array}{l}\text { Filing a permit } \\
\text { and project } \\
\text { schedule to the } \\
\text { Traffic Team }\end{array}$ \\
\hline $\begin{array}{l}\text { Parapet } \\
\text { Reinforci } \\
\text { ng }\end{array}$ & $\begin{array}{l}\text { Reinforc } \\
\text { ing } \\
\text { worker } \\
\text { is not } \\
\text { accordin } \\
\mathrm{g} \text { with } \\
\text { parapet } \\
\text { elevatio } \\
\mathrm{n}\end{array}$ & $\begin{array}{l}\text { Supervising on } \\
\text { reinforcing and } \\
\text { installing matrix }\end{array}$ \\
\hline $\begin{array}{l}\text { Parapet } \\
\text { Casting }\end{array}$ & $\begin{array}{l}\text { Highwa } \\
\text { y Patrol } \\
\text { Permissi } \\
\text { on }\end{array}$ & $\begin{array}{l}\text { Filing a permit } \\
\text { and project } \\
\text { schedule to the } \\
\text { Traffic Team }\end{array}$ \\
\hline Rigid & $\begin{array}{l}\text { Highwa } \\
\text { y Patrol }\end{array}$ & $\begin{array}{l}\text { Filing a permit } \\
\text { and project }\end{array}$ \\
\hline
\end{tabular}

\begin{tabular}{lll}
\hline & $\begin{array}{l}\text { Permissi } \\
\text { on }\end{array}$ & $\begin{array}{l}\text { schedule to the } \\
\text { Traffic Team }\end{array}$ \\
\hline Asphalt & $\begin{array}{l}\text { Highwa } \\
\text { y Patrol }\end{array}$ & $\begin{array}{l}\text { Filing a permit } \\
\text { and project }\end{array}$ \\
& $\begin{array}{l}\text { Permissi } \\
\text { schedule to the } \\
\text { on }\end{array}$ & Traffic Team \\
\hline \multicolumn{3}{c}{ Source: Personal Data }
\end{tabular}

4) Weekly Work Plan

Commonly known as Weekly Work Plan, it is a work list that optimistically will be done on a week asa result of project team discussion. In Zone 3, the project team consisted of a number executors will scheduling once a week to have a meeting on making Weekly Work Plan.

5) Daily Huddles

It is an activity to check the preparation of the Project Team to realize Weekly Work Plan (WWP) and required elements for project to maintain WWP that has been made by Project Team.

\section{Evaluation with Percent Plan Completed (PPC)}

PPC is achieved by calculating the sum of works volume that have been done divided by the sum of planned works volume (Robby, Steven, \& Andi, 2013). Here is the Equation (1) presented in PPC calculation.

PPC $(\%)=\frac{\Sigma \text { volume realisasi }}{\Sigma \text { volume rencana }} \times 100$

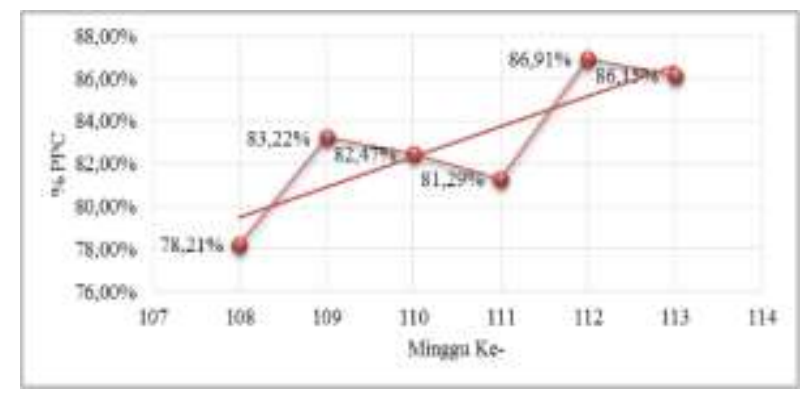

Figure 1. Percent Plan Completed Chart Source: Personal Data 
PPC Value is calculated based on work item on Weekly Work Plan (Setiaji, 2019). PPC Value on each week is calculated in total and average.

Presented in Table 2 are the result of PPC calculation recapitulation from Week 108 to 113 .

Table 2. PPC Value Recapitulation

\begin{tabular}{cc}
\hline Week- & PPC Value \\
\hline 108 & $78.21 \%$ \\
\hline 109 & $83.22 \%$ \\
\hline 110 & $82.47 \%$ \\
\hline 111 & $81.29 \%$ \\
\hline 112 & $86.91 \%$ \\
\hline 113 & $86.15 \%$ \\
\hline Average & $\mathbf{8 3 . 0 4 \%}$ \\
\hline
\end{tabular}

Source: Personal Data

After calculating the PPC Value per work item and make it into PPC per week, the next evaluation stage of LPS Concept is make the PPC Value chart. PPC Chart is presented on figure1.

The objective is to investigate the PPC Value trend with linear line and when the PPC Value is below the linear line trend.

\section{Pareto Chart Analysis}

As shown on Picture 1, the point on Week 108,111 , and 113 are below the PPC linear line trend. Therefore, follow-up is needed along with issues analysis using Pareto chart to investigate the constraint in priority concern.

Field observation and interview were done to investigate the cause of unfinished works. There are 49 unfinished works on weeks that have PPC value below PPC trend linear.
There are 5 constraints that are considered as the causes of unmatch realization toward Weekly Work Plan on Week 108, 111, and 113, namely:

1) Permit

2) Weather

3) Working Scope Change

3) Communication

Finished Overdue

The recapitulation of the constraint calculation result is presented on Table 3 .

Tabel 3. Constraint Calculation Result

\begin{tabular}{ccc}
\hline Constraint & Works & $\begin{array}{c}\text { Cummulative } \\
\text { Percentage }\end{array}$ \\
\hline Permission & 18 & $36.73 \%$ \\
\hline Communication & 11 & $59.18 \%$ \\
\hline Weather & 11 & $81.63 \%$ \\
\hline $\begin{array}{c}\text { Working Scope } \\
\text { Change }\end{array}$ & 5 & $91.84 \%$ \\
\hline $\begin{array}{c}\text { Finished } \\
\text { Overdue } \\
\text { Total }\end{array}$ & 4 & $100.00 \%$ \\
\hline \multicolumn{2}{c}{ Source: Personal Data }
\end{tabular}

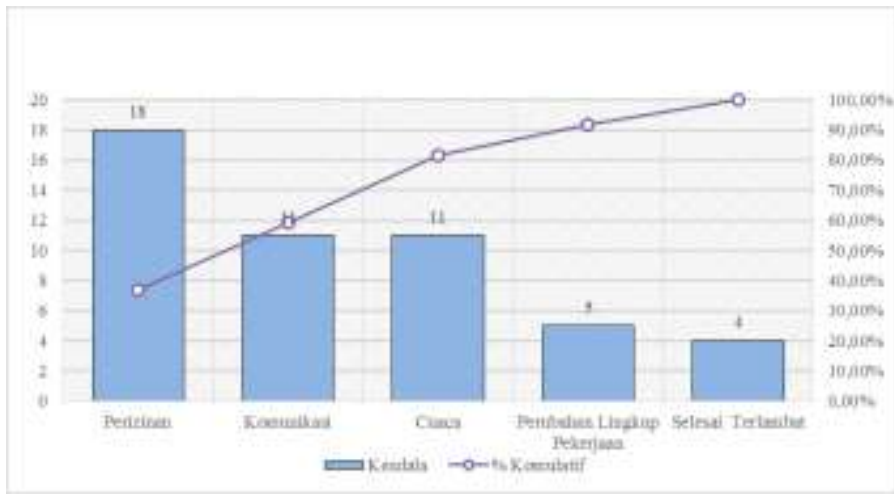

Figure 2. Pareto Chart on Constraint Variation Source: Personal Data 
The calculation result is interpreted into Pareto chart as shown on Figure 2.

Pareto Chart was first time introduced by an Italian economist named Vilfredo Pareto (1848-1923). On 1906, he observed that $80 \%$ of Italy's income is possessed by $20 \%$ of total population. Pareto Principal is known as 80, -20 rules, means that in many occasion, approximately $80 \%$ of the effect has $20 \%$ causes (Juran, 2008).

Based on the information gained from the Pareto chart, the cumulative percentage of $20 \%$ shown the permit issue. It makes the submittals as the cause of the constraints and other $80 \%$ issues. As a result, the top priority issue that needs to be concerned on Jakarta-Cikampek II Elevated Toll Road Project is the submittals.

\section{Follow-Up on Issue}

The challenge on development of Jakata-Cikampek II Elevated Toll Road Project was the location which was above the actively operated toll road. The traffic volume below it also quite high.

The Highway Police (Polisi Jalan Raya/PJR) also contributed along the progress. PJR only allowed the Project Team to work on the construction on window time, started from 10 PM until 5 AM. It might happen unexpectedly PJR asked the Project Team to stop the construction when it was considered distracting the traffic.

To avoid such condition, before the Project Team worked on the construction, they gave the Work Permit on Lane Disruption which next was handed over to Traffic Team of Waskita Karya (Hardiansyah, 2019). Then, the Team Traffic followed up the Work Permit to PJR in order to make them have the construction project schedule.

\section{ACKNOWLEDGEMENT}

In this opportunity, the author would like to thank Research and Service Center of Politeknik Negeri Jakarta for the final research project fund given to the students that has already made this research successfully done. The author also acknowledges to all the parties involved in contributing to this research.

\section{CONCLUSION}

The concept of management in Last Planner System on Jakarta-Cikampek II Elevated Toll Road Project is used to identify the constrains before making Weekly Work Plan and to increase the Executor's reliability in making more realistic plan instead of the optimistic one to make better PPC Value result.

The result of this research shows that Jakarta-Cikampek II Elevated Toll Road Project has PPC Value of $83,04 \%$. From the analysis result, the priority issue that needs to be more concerned than the other issues is permit issue.

\section{REFERENCES}

Arifin, A. (2017). Eksplorasi Penggunaan Last Planner System untuk Monitoring dan Evaluasi Progress Pekerjaan proyek Konstruksi (Studi Kasus Proyek Pembangunan Tahap Dua Gedung IRNAD RSUP Dr. Soeradji Tirtonrgoro Klaten. Yogyakarta: Fakultas Teknik Universitas Gadjah Mada. 
Ballard, H. G. (2000). The Last Planner System of Production Control. UK: School of Civil Engineering Faculty of Engineering.

Hamzeh, F. R., Ballard, H. G., \& Tommelein, I. D. (2008). Improving Construction Workflow-The Connective Role of Lookahead Planning. Proceedings of the 16th Annual Confrence of The International Group for Lean Construction (pp. 635-646). Manchester UK: IGLC.

Hardiansyah. (2019, Juli 6). Mengetahui cara Tim Proyek menjaga komitmen Stakeholders. Bekasi: PT Waskita Karya.

Juran, J. (2008, March). Pioneer in Quality Control. New York Times, hal. 103.

Nursin, A. (2019). Last Planner System. Depok: Politeknik Negeri Jakarta.

PT Jasa Marga Jalan Layang Cikampek. (2019). Laporan Minguan Proyek Jalan Tol Jakarta-Cikampek II Elevated. Bekasi: PT Jasa Marga Jalan Layang Cikampek.

PT Jasa Marga Jalan Layang Cikampek. (2019). Presentasi Kunjungan PT Jasa Marga Jalan Layang Cikampek. Bekasi: PT Jasa Marga Jalan Layang Cikampek.

Robby, Steven, \& Andi. (2013). Perhitungan Percent Plan Completed dan Identifikasi Faktor Tidak Tercapainya
Rencana Pekerjaan Pada Suatu Proyek. Jurnal Dimensi Pratama Teknik Sipil, Vol 2. No.2.

Setiaji, W. (2019, Juli 4). Mengetahui alur pembuatan Weekly Work Plan. Bekasi: PT Waskita Karya. 